\title{
BIODIVERSITY OF MEDICINAL PLANTS FROM THE NORTHERN BLACK SEA COASTAL WETLANDS PART 2 - DURANKULAK LAKE PROTECTED AREA
}

\author{
Dobri Ivanov, Djeni Cherneva
}

\author{
Department of Biology, Faculty of Pharmacy, Medical University of Varna
}

\begin{abstract}
The present study aims to supplement the available research data on medicinal plants of the Durankulak Lake area. Survey results established a significant variety of medicinal plants: 112 species of higher plants referring to 34 families and 87 genera. The prevailing biological type is the herbaceous perennial type (67 species or 60\%). Considering moisture and humidity as a factor, the mesophyte plants (presented by 48 species or $43 \%$ ) occupy dominant position among the medicinal plants. Eurasian geo-elements (20 species or $18 \%$ ) are predominant, followed by the Euro-Mediterranean (18 species or 16\%), sub-Mediterranean (17 species or 15\%). Among the medicinal plants there is only one Balkan endemic species. Medicinal plants of conservation significance represent $11.4 \%$ or 13 species. The established medicinal plants have more than 30 types of healing actions, one fifth of which is used primarily for the treatment of gastrointestinal diseases. The species in which the aboveground part (herba) is collected for plant substance constitute half of the established medicinal plants. The in-depth analysis benefits the comparison of the biodiversity of medicinal plants in the Durankulak Lake wetland area with other wetlands.
\end{abstract}

Keywords: wetlands, medicinal plants, Durankulak Lake

\section{INTRODUCTION}

In recent years, the interest in the flora and vegetation of the wetlands has been increasing, involving assessment of their environmental and conservation significance, along with assessment of their importance in the formation of high-productive communities which are the basis for different food chains and ensure the existence of a variety of organisms - a guarantee of ecosystem sustainability (1).

Address for correspondence:

Djeni Cherneva

Faculty of Pharmacy

84 Tzar Osvoboditel Blvd

9002 Varna

e-mail:djeni-cherneva@abv.bg

Received: May 14, 2018

Accepted: May 31, 2018
In this regard, the Northern Black Sea coastal wetlands in Bulgaria represent a research interest. They are an important moulding factor contributing to the existence of a rich and varied flora including a wide variety of medicinal plants which have not yet been fully explored. Information on various aspects of medicinal plants can be found in the research studies of Dimitrov et al. (2000), Filipova et al. (2002), Ivanov et al. (2002), Ivanov and Filipova (2008), and Zahariev et al. (2016) (1-5).

In view of the conservation and rational use of this biological resource our objectives are to supplement the available data on medicinal plants in the Northern Black Sea wetland area of Durankulak Lake by producing a taxonomic analysis and creating a database on their ecological and biological characteristics, floristic elements, conservation significance and conservation status assessment. Along with the above, we aim to collect available data on the healing 
Biodiversity of Medicinal Plants from the Northern Black Sea Coastal Wetlands. Part 2 - Durankulak Lake ...

action and usable parts of the established medicinal plants, as well as data on the diseases they are applicable for.

\section{MATERIALS AND METHODS}

The surveyed area is situated in the most northeastern part of Bulgaria, approximately $6 \mathrm{~km}$ from the Bulgarian-Romanian border and $15 \mathrm{~km}$ north of Shabla, Varna district (6). The wetland area of 350 ha includes the Durankulak Lake coastal firth, adjacent sand dunes, marine aquaria, grasslands, forest-tree and shrub communities and arable land (1).

Field surveys were based on the inventory route technique and conducted during the 2013-2015 vegetation seasons. The floristic analysis was performed after Tolmachev (1974) (7). The species were determined according to "Flora of the Republic of Bulgaria" (8-12), and "Identification Guide to Higher Plants in Bulgaria" (13). The analysis of the floristic elements is according to the classification of Asyov and Petrova, (2006) (14).

The status of medicinal plants is determined on the basis of the Medicinal Plants Act (15) and the National Strategy for Biodiversity Conservation (16).

The conservation status of the species was defined at a national level according to the "Red Data Book of the Republic of Bulgaria" (17), the Biological Diversity Act (18), Order RD-83 of 03.02.2014 (19), and at an international level as defined in $\mathrm{Lu}-$ cas (1983) (20), the IUCN Red List (21), Appendix 1 to the Convention on the Conservation of European Wildlife and Natural Habitats (22), and the Appendices to the Convention on International Trade in Endangered Species of Wild Fauna and Flora (23). Endemism is presented at the level of Balkan and Bulgarian endemics, according to the "Balkan Endemics in the Bulgarian Flora" (24) and the "List of Bulgarian Endemic Plants" (25).

The phytotherapeutic properties of the plants are described as per Petkov (1982) (26), Asenov (1988) (27), and Nikolov (2006) (28); and their applications in traditional medicine according to Petkov (1982) (26).

\section{RESULTS AND DISCUSSION}

Results manifest a considerable diversity of medicinal plants in the Durankulak Lake wetlands: out of 305 species of higher plants identified in the flo- ra of the area, our survey established 112 species as medicinal plants within the meaning of Medicinal Plants Act (15). Of these, 105 (94\%) are such under the Medicinal Plants Act (15), and 54 species (48\%) - according to the National Strategy for Biodiversity (16). In total, medicinal plants represent $37 \%$ of the higher flora of the surveyed area and 15\% of the wild growing medicinal plants in Bulgaria.

The established medicinal plants refer taxonomically to 34 families and 87 genera. With the largest number of species is the Asteraceae - 24 species or 21\%; Lamiaceae - 16 species or 16\%; Rosaceae - 10 species or $9 \%$; and Fabaceae - 9 species or $8 \%$, the totals making for $52 \%$ of the established species. It is noteworthy that the Asteraceae, Lamiaceae, Rosaceae, and Fabaceae families are among the most species-rich families typical for the flora of the area. On the other hand, the Poaceae, Apiaceae, Cyperaceae and Caryophyllaceae (1) families are represented by only 1 species of medicinal plant. Families with the most genera of medicinal plants are: Asteraceae (17), Lamiaceae (11), Rosaceae (8), Fabaceae (6) and Ranunculaceae (4); the Asteraceae and Lamiaceae being among the richest in genera families of the flora of the area. Genera with the highest number of medicinal plants are Arthemisia (4), Mentha (3), Teucrium (3), Potentilla (3), Galium (3).

The prevailing biology type is the herbaceous perennial type (67 species or $60 \%$ ), followed by annual grass plants (21 species or 19\%), shrubs (11 species or $10 \%$ ) and biennials (6 species or 5\%). Annuals to biennials are $4(4 \%)$, while biennial to perennial, typical tree species and shrubs to trees are represented by only 1 species each (1\%). Analysis demonstrates that the distribution of the biological types established for the area follows that of the flora for the area. (1).

Considering moisture and humidity as a factor, dominating are the mesophyte plants (48 species or $43 \%$ ), followed by the xerophytes (44 species or $39 \%$ ) and hygrophytes (19 species or $17 \%$ ). Hydrophytes, however, although dominating the lake's vegetation, are represented by only 1 species of medicinal plant or $1 \%$. Medicinal plants have similar ecological structure to the one of the entire flora of the area. It is noteworthy the significant presence of ruderal and xerophyte species in the flora of the area (1), as well as among the medicinal plants. 
Dobri Ivanov, Djeni Cherneva

Primary analysis of the floristic elements suggests prevalence of Eurasian geo-elements (20 species or $18 \%)$. Second to them are the Euro-Mediterranean (18 species or $16 \%$ ), followed by sub-Mediterranean (17 species or 15\%), and cosmopolitan (13 species or $12 \%)$. The species with different types of Mediterranean distribution account in total for 40 species, representing $36 \%$ of the total number of species. There are 48 species with different types of European distribution which represents $43 \%$ of the total number of species. Almost the same distribution (with predominantly Eurasian, Mediterranean and cosmopolitan geo-elements) is manifested by the analysis of the floristic elements of the Durankulak Lake area flora (1). The presence of a large number of cosmopolitans among the medicinal species (12\%), similar to that of the flora of the area, is mainly due to the fact that the survey covers a wetland area dominated by marsh plants the majority of which are cosmopolitans.

There is only one Balkan endemic plant among the medicinal plants of the studied wetland area: Achillea clypeolata S. et S.

Medicinal plants of conservation significance in the area are 13 species (11.4\%), which depending on the degree of threat to the biological diversity are referred to different conservation categories and status. They account for almost one third of the 32 conservation significant species of the flora of the survey area (1).

In European Red List (21) for endangered species are included four species from the survey area under the category of near-threatened: Alisma plan- tago-aquatica L., Bidens tripartita L., Pulicaria vulgaris Gaerth and Butomus umbellatus L. In Bulgarian Red Data Book for endangered species are included Eryngium maritimum L. and Taraxacum bessarabicum (Horn.) Hand.-Mazz. According to Bulgarian Biological Diversity Act, Appendix 3, Article 37, protected plants are Eryngium maritimum L. and Artemisia lerchiana Web. (18). As per Bulgarian Biological Diversity Act, Appendix 4, Article 41, conservation measures and regulated use is required only for Heli-syssum arenarium (L.) Moench (18). There are three species prohibited for collection from their natural habitats: Helichrysum arenarium (L.) Moench, Althea officinalis L. and Adonis vernalis $\mathrm{L}$. The above is according to Order № RD-83 of 03.02.2014 of the Minister for the Environment and Water issued on the basis of the Medicinal Plants Act, Article 10 (19). There is one medicinal plant under special protection and use regulations - Galium odoratum (L.) Scop, for which maximum quantities for collection from its natural habitat are annually set. The above restriction is set by Order № RD-83 of 03.02.2014 of the Minister for the Environment and Water issued on the basis of the Medicinal Plants Act, Article 10 (19).

Based on available research data for the healing activity and plant substances, we grouped the medicinal plants of the studied Durankulak Lake area according to the diseases they are applicable for (Table 1).

Analysis indicates that 23 species, representing one fifth of the featured medicinal plants are used

Table 1. Groups of diseases, healing action and plant substance

\begin{tabular}{l|ll} 
Species & Healing action $\quad$ Plant substance
\end{tabular}

\section{Plants used for treatment of cardiovascular diseases}

\begin{tabular}{|l|l|l|}
\hline Adonis vernalis L. & cardiovascular, diuretic, sedative & Herba Adonidis \\
\hline Crataegus monogyna Jacq. & $\begin{array}{l}\text { cardiovascular, decreasing blood pressure, } \\
\text { sedative }\end{array}$ & Folium, flos et fructus Crataegi \\
\hline Digitalis lanata Ehrh. & cardiovascular & Folium Digitalis lanatae \\
\hline Lycopus europaeus L. & antiarrhythmic & Herba Lycopi \\
\hline Thalictrum minus L. & hypotensive, antitumor action & Herba Talictri \\
\hline Plants used for treatment of gastrointestinal diseases & \\
\hline Artemisia absinthium L. & appetite exciting & Herba Absinthii \\
\hline
\end{tabular}


Biodiversity of Medicinal Plants from the Northern Black Sea Coastal Wetlands. Part 2 - Durankulak Lake ...

\begin{tabular}{|c|c|c|}
\hline Agrimonia eupatoria L. & $\begin{array}{l}\text { astringent, constipative, stimulates the } \\
\text { release of bile, appetite exciting, diuretic, } \\
\text { antimicrobial, antiviral action }\end{array}$ & Herba Agrimoniae \\
\hline Artemisia vulgaris $\mathrm{L}$. & $\begin{array}{l}\text { appetite exciting, sedative, haemostatic } \\
\text { action }\end{array}$ & Herba et radix Artemisiae \\
\hline Ballota nigra L. & spasmolytic, anti-inflammatory, analgesic & Herba Ballotae \\
\hline Centaurea cyanus L. & $\begin{array}{l}\text { appetite exciting, diuretic, stimulates the } \\
\text { release of bile }\end{array}$ & Flores Centaureae \\
\hline Centaurium erythraea Raf. & appetite exciting & Herba Centhaurii \\
\hline Cichorium inthybus L. & $\begin{array}{l}\text { appetite exciting, diuretic, stimulates the } \\
\text { release of bile }\end{array}$ & Radix Cichorii \\
\hline Convolvulus arvensis L. & laxative, diuretic, epithelium tonic & Herba Convolvuli \\
\hline Cuscuta europaea L. & purgative, diuretic, analgesic & Herba Cuscutae \\
\hline Datura stramonium L. & spasmolytic & Folium Stramonii \\
\hline Lotus corniculatus L. & analgesic, spasmolytic & Herba et fructus Corniculati \\
\hline Lythrum salicaria $\mathrm{L}$. & $\begin{array}{l}\text { constipative, haemostatic action, antiseptic, } \\
\text { spasmolytic }\end{array}$ & Herba Litrii \\
\hline Malva sylvestris $\mathrm{L}$. & spasmolytic, expectorant, sedative & Flos et folium Malvae sylvestris \\
\hline Nigella arvensis $\mathrm{L}$. & carminative, laxative & Semen Nigellae \\
\hline Potentila reptans $\mathrm{L}$. & $\begin{array}{l}\text { constipative, haemostatic action, } \\
\text { anti-inflammatory }\end{array}$ & Herba Potentillae reptani \\
\hline Potentilla bornmuelleri Borb. & $\begin{array}{l}\text { astringent, haemostatic action, } \\
\text { anti-inflammatory }\end{array}$ & Herba Potentillae \\
\hline Prunus spinosa L. & astringent, laxative, diuretic & Flos et fructus Pruni spinosae \\
\hline Pulicaria vulgaris Gaertn. & laxative, insecticide & Herba et radix Pulicariae \\
\hline Rhamnus catharticus L. & laxative, anti-inflammatory & $\begin{array}{l}\text { Cortex, folium et fructus Rhamni } \\
\text { cathartici }\end{array}$ \\
\hline Rubus caesius L. & astringent, anti-inflammatory & $\begin{array}{l}\text { Radix, folium et flos Rubi } \\
\text { fruticosi }\end{array}$ \\
\hline Teucrium chamaedrys L. & $\begin{array}{l}\text { anti-inflammatory, analgesic, astringent, } \\
\text { constipative }\end{array}$ & Herba Teucrii \\
\hline Teucrium polium L. & constipative, analgesic & Herba Teucrii \\
\hline Teucrium scordium $\mathrm{L}$. & $\begin{array}{l}\text { anti-inflammatory, analgesic, astringent, } \\
\text { constipative }\end{array}$ & Herba Teucrii \\
\hline \multicolumn{3}{|c|}{ Plants used for treatment of liver and biliary tract } \\
\hline Marrubium peregrinum L. & stimulates the release of bile, spasmolytic & Herba Marrubii \\
\hline Mentha aquatica L. & spasmolytic, antiseptic & Folium Menthae aquaticae \\
\hline Mentha pulegium L. & $\begin{array}{l}\text { stimulates the production of bile, } \\
\text { spasmolytic, antiseptic }\end{array}$ & Folium Menthae pulegiumae \\
\hline Mentha spicata L. & $\begin{array}{l}\text { stimulates the production of bile, } \\
\text { spasmolytic, antiseptic }\end{array}$ & Folium Menthae spicatae \\
\hline Solanum nigrum L. & spasmolytic, sedative, analgesic & Herba Solani nigri \\
\hline $\begin{array}{l}\text { Taraxacum bessarabicum } \\
\text { (Horn.) Hand.-Mazz. }\end{array}$ & stimulates the release of bile, diuretic & Herba et radix Taraxaci \\
\hline
\end{tabular}


Dobri Ivanov, Djeni Cherneva

\begin{tabular}{|c|c|c|}
\hline Taraxacum officinale Veb. & stimulates the release of bile, diuretic & Herba et radix Taraxaci \\
\hline \multicolumn{3}{|c|}{ Plants used for treatment of respiratory diseases } \\
\hline Althea officinalis L. & expectorant,anti-inflammatory & Radix Althaeae \\
\hline Carthamus lanatus L. & anti-inflammatory & Flos et radix Carthamus \\
\hline Iris pseudacorus L. & expectorant, anti-inflammatory, analgesic & Radix Iridis \\
\hline Iris pumila $\mathrm{L}$. & anti-inflammatory & Radix Iridis \\
\hline Paliurus spina-crhisti Mill. & $\begin{array}{l}\text { expectorant, anti-inflammatory, } \\
\text { spasmolytic }\end{array}$ & Fructus Paliuri \\
\hline Papaver rhoeas $\mathrm{L}$. & expectorant & Flos Rhoeados \\
\hline Sideritis montana L. & expectorant & Herba Sideritis csardicae \\
\hline Trifolium pratense $\mathrm{L}$. & expectorant, diuretic, anti-inflammatory & Flos Trifolii pratensisis \\
\hline $\begin{array}{l}\text { Verbascum tapsiforme } \\
\text { Schrad. }\end{array}$ & expectorant, anti-inflammatory & Flos Verbasci \\
\hline Veronica prostrata $\mathrm{L}$. & $\begin{array}{l}\text { expectorant, antiseptic, anti-inflammatory, } \\
\text { expectorant, diuretic }\end{array}$ & Herba Veroniciae \\
\hline \multicolumn{3}{|c|}{ Plants used for treatment of kidney and urinary tract diseases } \\
\hline Alisma plantago-aquatica $\mathrm{L}$. & diuretic & Rhizoma Plantaginis aquaticae \\
\hline Arctium lappa L & diuretic, anti-ulcer & Radix Arctii lappae \\
\hline Carduus acanthoides L. & $\begin{array}{l}\text { diuretic, strengthens the secretion of the } \\
\text { digestive tract }\end{array}$ & Herba Carduus acanthii \\
\hline Cynodon dactylon $\mathrm{L}$. & diuretic, laxative & Rhizoma Gramminis italici \\
\hline Eryngium campestre $\mathrm{L}$ & diuretic, spasmolytic & Radix Eringii \\
\hline Eryngium maritimum L. & diuretic, spasmolytic & Radix Eringii \\
\hline Galium odoratum (L.) Scop. & $\begin{array}{l}\text { diuretic, stimulation of sweat, anti- } \\
\text { inflammatory, spasmolytic }\end{array}$ & Herba Asperule \\
\hline Galium palustre L. & diuretic, astringent, anti-inflammatory, & Herba Galii palustri \\
\hline Galium verum $\mathrm{L}$. & diuretic, laxative, analgesic & Herba Galii veri \\
\hline Ononis pusilla L. & diuretic, anti-inflammatory & Radix Ononidis \\
\hline Ononis spinosa L. & diuretic, anti-inflammatory & Radix Ononidis \\
\hline Polygonum aviculare (L.) L. & diuretic, astringent, haemostatic action & Herba Polygoni avicularis \\
\hline Rosa canina $\mathrm{L}$. & $\begin{array}{l}\text { diuretic, against scurvy, strengthens the } \\
\text { immune system }\end{array}$ & Fructus Rosae \\
\hline Sambucus ebulus L. & diuretic, antiseptic, expectorant & Radix, fructus et flos Ebuli \\
\hline \multicolumn{3}{|c|}{ Plants used for treatment of rheumatic and colds diseases } \\
\hline Filipendula vulgaris Moench. & anti-rheumatic, diuretic & Herba Ulmariae \\
\hline Lemna minor L. & $\begin{array}{l}\text { antipyretic, anti-inflammatory, analgesic, } \\
\text { stimulating bile release }\end{array}$ & Herba Lemnae \\
\hline Salix alba L. & antipyretic, anti-rheumatic & Cortex Salicis \\
\hline
\end{tabular}


Biodiversity of Medicinal Plants from the Northern Black Sea Coastal Wetlands. Part 2 - Durankulak Lake ...

\begin{tabular}{|c|c|c|}
\hline Salvia aethiopis $\mathrm{L}$. & anti-inflammatory & Folium Salviae \\
\hline Salvia pratensis $\mathrm{L}$. & anti-inflammatory & Folium Salviae \\
\hline Sambucus nigra L. & stimulation of sweat, diuretic & Flos et fructus Sambuci \\
\hline Solanum dulcamara L. & $\begin{array}{l}\text { stimulation of sweat, anti-inflammatory, } \\
\text { diuretic, laxative }\end{array}$ & Herba dulcamarae \\
\hline Verbena officinalis $\mathrm{L}$. & $\begin{array}{l}\text { stimulation of sweat, antipyretic, sedative, } \\
\text { strengthening the body }\end{array}$ & Herba Verbenae \\
\hline Xanthium spinosum L. & anti-rheumatic, anti-inflammatory & Herba et fructus Xanthtii spinosi \\
\hline Xanthium strumarium L. & anti-rheumatic, anti-inflammatory & $\begin{array}{l}\text { Herba et fructus Xanthii } \\
\text { strumarii }\end{array}$ \\
\hline \multicolumn{3}{|c|}{ Plants used for treatment of metabolic and endocrine diseases } \\
\hline Galega officinalis L. & hypoglycaemic, diuretic & Herba Galegae \\
\hline $\begin{array}{l}\text { Helichrysum arenarium (L.) } \\
\text { Moench. }\end{array}$ & $\begin{array}{l}\text { stimulates metabolism, hypoglycaemic, } \\
\text { appetite exciting }\end{array}$ & Herba et flos Helichrysii arenarii \\
\hline Lactuca serriola L. & stimulates metabolism & Herba Lactucae \\
\hline \multicolumn{3}{|c|}{ Plants used for treatment of parasitic diseases } \\
\hline Artemisia lerchiana Web. & anthelmintic & Herba Absinthii \\
\hline Artemisia maritima L. & anthelmintic & Flos Artemisiae \\
\hline Xeranthemum annuum L. & $\begin{array}{l}\text { antiviral action, antibacterial, antimycotic, } \\
\text { strengthens the immune system }\end{array}$ & Herba Xerantemi \\
\hline \multicolumn{3}{|c|}{ Plants that affect central nervous system } \\
\hline Conium maculatum L. & analgesic & Fructus et herba Conii \\
\hline Consolida regalis S. F. Gray & anthelmintic, laxative & Herba et semen Consolidae \\
\hline Heliotropium europaeum L. & spasmolytic & $\begin{array}{l}\text { Rizoma et herba Heliotropii } \\
\text { europei }\end{array}$ \\
\hline Leonurus cardiaca $\mathrm{L}$. & $\begin{array}{l}\text { sedative, lowers blood pressure, } \\
\text { antiarrhythmic }\end{array}$ & Herba Leonuri \\
\hline Melilotus alba Med. & sedative & Herba Meliloti \\
\hline Melilotus officinalis (L.) Pall. & sedative & Herba Meliloti \\
\hline Scutellaria altissima L. & spasmolytic, astringent, diuretic & Herba Scitelarii \\
\hline \multicolumn{3}{|c|}{ Plants with predominantly haemostatic action } \\
\hline Achillea clypeolata S. et S & haemostatic action, anti-inflammatory & Herba Millefolii \\
\hline Achillea millefolium L. & haemostatic action, anti-inflammatory & Herba Millefolii \\
\hline Bidens tripartita L. & astringent, diuretic, stimulation of sweat & Herba Bidentis \\
\hline Echium italicum L. & $\begin{array}{l}\text { haemostatic action, expectorant, against } \\
\text { epilepsy }\end{array}$ & Radix et folium Echii italici \\
\hline $\begin{array}{l}\text { Persicaria hydropiper (L.) } \\
\text { Opiz. }\end{array}$ & haemostatic action & Herba Polygoni hydropiperis \\
\hline Plumbago europaea L. & anti-inflammatory, astringent & Radix et herba Plumbaginis \\
\hline
\end{tabular}


Dobri Ivanov, Djeni Cherneva

\begin{tabular}{|c|c|c|}
\hline Potentila argentea $\mathrm{L}$. & $\begin{array}{l}\text { astringent, haemostatic action, } \\
\text { anti-inflammatory }\end{array}$ & Rhizoma Potentillae argenteae \\
\hline Sangusorba minor Scop. & $\begin{array}{l}\text { haemostatic action, astringent, constipative, } \\
\text { anti-inflammatory }\end{array}$ & Rhizona et radix Sanguisorbe \\
\hline Urtica dioica L. & haemostatic action, diuretic & Folium Urticae \\
\hline \multicolumn{3}{|c|}{ Plants used primarily for wound healing } \\
\hline Hypericum perforatum $\mathrm{L}$. & $\begin{array}{l}\text { anti-inflammatory, astringent, anti-ulcer, } \\
\text { haemostatic action, sedative }\end{array}$ & Herba Hyperici \\
\hline Plantago lanceolata L. & anti-inflammatory, laxative, anti-ulcer & $\begin{array}{l}\text { Folium et herba Plantaginis } \\
\text { lanceolatae }\end{array}$ \\
\hline Plantago major L. & anti-inflammatory, laxative, anti-ulcer & $\begin{array}{l}\text { Folium et herba Plantaginis } \\
\text { majoris }\end{array}$ \\
\hline Stachys recta $\mathrm{L}$. & regenerative & Herba Stahis recti \\
\hline \multicolumn{3}{|l|}{ Plants used in skin diseases } \\
\hline Euphorbia amygdaloides L. & keratolytic & Succus Euphorbiae \\
\hline Euphorbia cyparissias L. & keratolytic & Succus Euphorbiae \\
\hline \multicolumn{3}{|c|}{ Plants with other types of actions } \\
\hline Anthemis tinctoria $\mathrm{L}$. & hair bleaching & $\begin{array}{l}\text { Fructus, folium et cortex Anthemi } \\
\text { tinctorii }\end{array}$ \\
\hline Butomus umbellatus L. & nutrient & Rizoma Butomi \\
\hline Chenopodium album L. & nutrient & Herba Chenopodii \\
\hline Chenopodium hybridum L. & nutrient & Herba Chenopodii \\
\hline Echinops sphaerocephalus L. & strengthening the body & Fructus Ehinopsis \\
\hline Lathyrus tuberosus L. & fodder & Herba Lathyri \\
\hline Salicornia europaea L. & nutrient & Herba Salicornae \\
\hline Trifolium repens $\mathrm{L}$. & fodder & Herba Trifolii \\
\hline
\end{tabular}

mainly for treatment of gastrointestinal diseases. The remaining groups of diseases are treated by half that number of species: for the treatment of kidney diseases and urinary tract diseases - 13 species; for treatment of respiratory diseases - 10 species; as haemostatic agents - 9 species; for rheumatic and common cold diseases - 8 species; for diseases of the liver and biliary tract - 7 species, for treatment of the central nervous system -7 species.

The medicinal plants established for the area have a wide variety of more than 30 types of healing action. Most of the medicinal plants of the studied area have diuretic (12 species) and anti-inflammato- ry (8 species) activity. Together they account for one fifth of the analysed medicinal plants. The remaining types of treatment activity are associated with 6 and less than 6 species.

Different vegetative and generative parts of the established medicinal plants are used as plant substances. The species in which the aboveground part (herba) of the plant is collected for plant substance dominate above all and constitute half of the established for the area medicinal plants. From a quarter of the species can be collected different plant parts. 
Biodiversity of Medicinal Plants from the Northern Black Sea Coastal Wetlands. Part 2 - Durankulak Lake ...

\section{CONCLUSION}

The in-depth analysis benefits the comparison of the biodiversity of medicinal plants in the Durankulak Lake wetland area with other wetlands which is an integral part of the study of the biodiversity of medicinal plants in Bulgaria. On the basis of the results obtained future research on resources can be performed in view of conservation and rational use of resources, along with promotion of the benefits and significance of wetland areas in the life of local population.

\section{REFERENCES}

1. Dimitrov D, Filipova-Marinova M, Ivanov D. Flora and vegetation in the region of Durankulak Lake. Varna: Proceedings of the National Museum. 2000; 30-31 (45-46): 314-332. (In Bulgarian).

2. Marinova-Filipova M, Ivanov D, Dimitrov D. Flora and vegetation in the region of Shabla and Ezerets lakes. Varna: Proceedings of the National $\mathrm{Mu}-$ seum Varna. 2002; 32-33 (47-48): 341-363. (In Bulgarian).

3. Ivanov D, Filipova-Marinova M, Dimitrov D. Flora and vegetation of the nature complex „Kamchia“. Ann. Sof. Univ. 2002; Book 2 - Botany, Vol. 92: 39-67.

4. Ivanov D, Filipova-Marinova M. Medicinal plants of wetlands along the Northern Black Sea coast. Proc Mus Ist Med; 2008; 4-5: 50-57. (In Bulgarian).

5. Zahariev D, Boycheva P, Kosev K. Review on the medicinal plants of the north black sea coast (Bulgaria). Ann. Sof. Univ. Faculty of biology. book 2 . 2016; 99: 100-114.

6. Georgiev D. et al. Management Plan of the Durankulak Lake Nature Complex. Ministry of Environment and Water / Bulgarian-Swiss Biodiversity Conservation Program. 1998.

7. Tolmachev AI. Introduction to Plant Geography. Publishing house of the Leningrad University. 1974. (In Russian).

8. Jordanov D. editor. Florae Reipublicae Popularis Bulgaricae. Vol. I-IX. Serdicae: Aedibus Acad. Sci. Bulgaricae; 1963-1989. (In Bulgarian).

9. Velchev V. editor. Florae Reipublicae Popularis Bulgaricae. Vol. 8. Serdicae: Aedibus Acad. Sci. Bulgaricae; 1982; 518 pp. (In Bulgarian).
10. Velchev V. editor. Florae Reipublicae Popularis Bulgaricae. Vol. 9. Serdicae: Aedibus Acad. Sci. Bulgaricae; 1989; 539 pp. (In Bulgarian).

11. Peev D. editor. Flora of the Republic of Bulgaria. Vol. XI, Sofia: Prof. M. Drinov Acad. Publ; 2013; 523 pp. (In Bulgarian).

12. Kozhuharov S. editor. Flora of the Republic of Bulgaria, Vol. X-XI. Sofia: Prof. M. Drinov Acad.Publ; 1995; 428 pp. (In Bulgarian).

13. Kozhuharov S. editor. Andreev N, Anchev M, Kozhuharov S, Markova M, Peev D, Petrova A. Determinant of the vascular plants in Bulgaria. Sofia: Science and art; 1992.

14. Assyov B, Petrova A, Dimitrov D, Vassilev R. Conspectus of the Bulgarian vascular flora. Distribution maps and floristic elements. Sofia: Bulgarian Biodiversity Foundation; 2006; 452 pp. (In Bulgarian).

15. Medicinal Plants Act of the Republic of Bulgaria. Annex. State Gazette number 29, 7 April 2000. 9-29. Last amended in State Gazette number 98. 28 November 2014. (In Bulgarian).

16. Hardalova R, Evstatieva L, Gusev Ch. Characteristics of the resource from the wonderfully healing plants in Bulgaria and the provision for sustainable development. In: National strategy behind bio-diversity denomination. 1994; 2: 41-72. (In Bulgarian).

17. Peev D, et al. editors. Red Data Book of the Republic of Bulgaria. Vol. 1 Plants and fungi. - http://eecodb.bas.bg/rdb/bg/voll/Lycinund=html (accessed on 01.08.2013).

18. Law on Biodiversity of the Republic of Bulgaria. Annex. State Gazette number 77. 9 August 2002. Last amended in State Gazette number 76. 19 September 2017. (In Bulgarian).

19. Order NoRD-83 from 3 February 2014 for special arrangements for the conservation and use of medicinal plants. State Gazette number 14, 18 February 2014. (In Bulgarian).

20. Lukas G. List of Rare Threatened and Endemic Plants in Europe. Strasbourg: Council of Europe; 1983.

21. The IUCN Red List of Threatened species. 2014.3

22. Bern Convention, 1979: Convention on the Conservation of European Wildlife and Natural Habitats. Appendix I. 
23. CITES, 1975: Convention on International Trade in Endangered Species of Wild Fauna and Flora.

24. Petrova A, Vladimirov V. editors. Balkan endemics in the Bulgarian flora. Sofia: Phytologia Balcanica. 2010; 16 (2): 293 - 311.

25. Petrova A, Velchev V. List of Bulgarian endemic species. - In: Petrova A. (ed.) Atlas of Bulgarian Endemic Plants. Gea-Libris Ltd; Sofia; 2006; 399

pp.

26. Petkov V. editor. Contemporary phytotherapy. Sofia: Medicine and Physical Education; 1982. (In Bulgarian).

27. Asenov I, Nikolov S. Pharmacognosy. Sofia: Medicine and Physical Education; 1988. (In Bulgarian).

28. Nikolov S. editor. Specialized encyclopedia of medicinal plants in Bulgaria. Sofia: Trud; 2006; 566 pp. (In Bulgarian). 